\title{
Morphological and biochemical characterization of the aetiological agents of white piedra
}

\author{
Alba Regina Magalhães ${ }^{1 /+}$, Silvia Susana Bona de Mondino', Manuela da Silva², \\ Marilia Martins Nishikawa ${ }^{3}$ \\ Laboratório de Micologia, Instituto Biomédico 'Programa de Pós-Graduação em Patologia, Departamento de Patologia, Universidade \\ Federal Fluminense, Rua Marquês de Paraná 303, 24030-210, Niterói, RJ, Brasil ²Programa de Pós-Graduação em Vigilância \\ Sanitária ${ }^{3}$ Setor de Fungos de Referência, Departamento de Microbiologia, Instituto Nacional de Controle de Qualidade-Fiocruz, \\ Rio de Janeiro, RJ, Brasil
}

The Trichosporon genus is constituted by many species, of which Trichosporon ovoides and Trichosporon inkin are the causative agents of white piedra. They can cause nodules in genital hair or on the scalp. At present, Brazilian laboratory routines generally do not include the identification of the species of Trichosporon genus, which, although morphologically and physiologically distinct, present many similarities, making the identification difficult. The aim of this study was to identify the aetiological agents at the species level of white piedra from clinical specimens. Therefore, both the macro and micro morphology were studied, and physiological tests were performed. Trichosporon spp. was isolated from 10 clinical samples; T. ovoides was predominant, as it was found in seven samples, while T. inkin was identified just in two samples. One isolate could not be identified at the species level. T. inkin was identified for the first time as a white piedra agent in the hair shaft on child under the age of 10.

Key words: Trichosporon - white piedra - mycosis - phenotypic identification

Trichosporon Behrend is a genus that belongs to the Basidiomycota phylum, the Hymenomycetes class and the Trichosporonales order (Fell et al. 2000). It is characterised by blastoconidia and arthroconidia and has been traditionally considered as the agent of white piedra, a superficial mycosis that attacks genital hair or hair shafts, producing bright, soft and yellowish nodules (Lacaz et al. 1984). For many years, this genus was regarded as consisting of few species that were morphologically and biochemically variable and its main representative was Trichosporon beigelii (Küchenm \& Rabenh) Vuill., a synonym of Trichosporon cutaneum (Kreger-van Rij 1984). However, Guého et al. (1992b), after a thorough revision of the genus based on morphological, biochemical and molecular characterisations, identified six human pathogenic species: Trichosporon ovoides Behrend, Trichosporon inkin (Oho ex Ota) do Carmo-Souza and van Uden, Trichosporon asteroides, Trichosporon cutaneum, Trichosporon asahii and Trichosporon mucoides. In another study published in the same year, Guého et al. (1992a) demonstrated that $T$. ovoides should replace $T$. beigelii, considered to be of doubtful identity, which should not be retained or be applied to T. cutaneum, a species already identified by de Beurmann, Gougerot and Vaucher from skin samples (de Beurmann \& Gougerot 1909). T. ovoides and T. inkin that have been to man, are scalp and genital white piedra agents, respectively (Guého et al. 1992b, 1994).

+Corresponding author: regmag27@hotmail.com

Received 3 July 2008

Accepted 31 October 2008
White piedra, a mycosis that occurs in some animals, such as horses, monkeys and domestic animals, as well as humans (Kaplan 1959), is found within a wide geographical distribution, including tropical and temperate regions, occurring mainly in South America, Africa, Europe and Asia (Kamalam et al. 1981, Thérizol-Ferly et al. 1994, Ghorpade 2004, Schwartz 2004). There are also some cases in the USA (Elmer et al. 2002, Youker et al. 2003, Kiken et al. 2006) and it has been found to be endemic to Texas (Kalter et al. 1986). Although some authors recorded the disease in India, after three years of investigation, Kamalam et al. (1981) found just four cases of white piedra in that country.

From the referenced literature, the cases of genital white piedra were the most frequently reported in Brazil (Brito \& Costa 1966, Londero et al. 1966, Carneiro et al. 1971, 1973, Fishman et al. 1980, Zaror et al. 1989, Almeida et al. 1990); however, more recent studies refer mainly to scalp white piedra (Nora et al. 2002, Pontes et al. 2002b, Diniz \& Souza Filho 2005), with the exception of five cases of genital white piedra recorded in 2002 (Pontes et al. 2002a). In Brazil, the disease has been recorded in the states of Pará, Rio Grande do Sul, São Paulo, Rio de Janeiro, Paraíba and Espírito Santo (Brito \& Costa 1966, Londero et al. 1966, Fischman et al. 1980, Zaror et al. 1989, Gondim-Gonçalves et al. 1991, Nora et al. 2002, Pontes et al. 2002a, b, Diniz \& Souza Filho 2005).

The laboratory diagnosis of white piedra is based on direct morphological observations of the fungal elements present on the hair. These elements are round blastoconidia and arthroconidia agglomerated and bind together by a cement-like substance produced by the fungal hyphae and are found in the extrafollicular region of the hair in any hairy areas, including eyelas- 
hes, eyebrows, beard, moustache, scalp, axilla and genitals (Smith et al. 1973, Zaror et al. 1989, Almeida et al. 1990, Kiken et al. 2006). When the fungus invades the interior of the hair, it becomes fragile, splits and breaks easily (Kalter et al. 1986).

The mode of infection is not clear: some authors suggest that poor hygienic habits and sexual transmission, in the case of genital white piedra, in addition to heat and humidity, are predisposing factors (Fischman et al. 1980, Torssander et al. 1985, Kalter et al. 1986, Stenderup et al. 1986). Despite cases of white piedra in domestic animals, they are unlikely the source of transmission to human beings (Walzman \& Leeming 1989).

There are few reports on white piedra from which the aetiological agent has been identified at the species level. Consequently, the knowledge on the species that attack humans is very limited, as well as the information regarding this mycosis epidemiology. Thus, the purpose of this investigation was to identify at the species level the aetiological agents of white piedra in hospital patients.

\section{PATIENTS, MATERIALS AND METHODS}

This is a retrospective study using cultures that were macroscopically identified as the genus Trichosporon and preserved in freezers at $-20^{\circ} \mathrm{C}$ on Skin Milk medium (Difco, USA). The research project was submitted to the Research Ethical Committee of Santa Casa de Misericórdia of Rio de Janeiro (protocol number 016/07).

The fungal isolates were obtained from hair samples from patients with clinically suspected white piedra in metropolitan Rio de Janeiro and were sent to the Mycology Laboratory of the Dermatological Service of Santa Casa de Misericórdia of Rio de Janeiro from January 2003-December 2006. The identification of the isolates was based on macro and microscopic characteristics of the yeasts cultivated at $25^{\circ} \mathrm{C}$ from 2-10 days on YMA (yeast malt extract agar, Difco, USA) for macroscopy and MEA (malt extract agar, Merck, Germany) and CMA (corn meal agar, Difco, USA) for microscopy. The results of carbon and nitrogen assimilation tests conducted with cultures on YNB (yeast nitrogen base, Difco, USA) and on YCB (yeast carbon base, Difco, USA), respectively, were also used as characteristics for species-level identification, as were tests on Christensen's media (Difco, USA) and from growth on the vitamin free medium YVFB (yeast vitamin free base, Difco, USA), on YNB with $0.5 \%$ glucose containing $0.1 \%$ or $0.01 \%$ cycloheximide and on YMB (yeast malt extract broth, Difco, USA) at $37^{\circ} \mathrm{C}$ (Barnett et al. 2000). All assays were conducted over four weeks, with the exception of the urea hydrolysis test, which was up to seven days and nitrogen assimilation tests, which were up to 14 days.

Reference microorganisms T. ovoides INCQS 40270 (ATCC 90040) and T. inkin INCQS 40266 (ATCC 18020), acquired from the American Type Culture Collection and maintained in the Culture Collection of Instituto Nacional de Controle de Qualidade (INCQS) were used as control for the identification of the species in the different tests within this investigation.

\section{RESULTS}

Mycological results - Ten clinical isolates of Trichosporon from different hair samples and reference strains were studied. Fig. 1 shows piedric nodule caused by a white piedra agent on a hair shaft. The causative agent could be any Trichosporon species, since the macroscopic aspect of piedric nodule is the same regardless the white piedra agent. All the isolates hydrolysed urea and did not ferment carbohydrates. The physiological and biochemical tests in addition to the macro and microscopic characteristics allowed the identification at the species level of nine isolates, among them seven T.ovoides and two T.inkin. One isolate remained unidentified at the species level (Table I). The physiological and biochemical tests conducted for this isolate indicated $50 \%$ of $T$. ovoides and $50 \%$ of $T$. asteroids characteristics; however, the morphology observations did not allow differentiation between these two species. Therefore, further characterisations will be needed in order to identify this species. The identified T. ovoides and T. inkin species, including the reference strains $T$. ovoides INCQS 40270 (ATCC 90040) and T. inkin INCQS 40266 (ATCC 18020), showed variable profiles toward the assimilation of carbon and nitrogen sources (Table II). However, the hit probability calculated using the Yeast Identification PC Program version 4 (Barnett et al. 2000) for T. ovoides was $95-100 \%$ and $98-100 \%$ for $T$. inkin, both satisfactory values. The morphological features of the identified species $T$. ovoides and $T$. inkin are described below.

Trichosporon ovoides - Colonies of the isolates, including T. ovoides INCQS 40270 (ATCC 90040), on YMA after 10 days at $25^{\circ} \mathrm{C}$ attained a diameter of around $15 \mathrm{~mm}$ and were dry, farinose, irregularly folded at the centre with deep radial fissures in some isolates and with a flat marginal zone, at first appearing as cream coloured then becoming white (Fig. 2A). The microscopic observations of the cultures on MEA after two days incubation at $25^{\circ} \mathrm{C}$ showed blastoconidia, many septate hyphae and

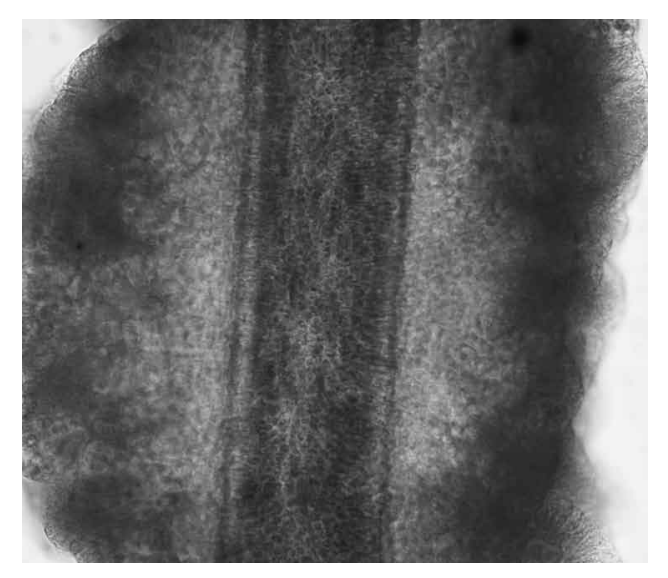

Fig. 1: piedric nodule involving hair shaft (KOH, 200X), courtesy of Dermatological Service of Santa Casa da Misericórdia, Rio de Janeiro, Brazil. 
TABLE I

Summary of Trichosporon ovoides and Trichosporon inkin strains from scalp and genital infections

\begin{tabular}{lcccc}
\hline $\begin{array}{l}\text { INCQS } \\
\text { Accession N }\end{array}$ & $\begin{array}{c}\text { Age } \\
\text { (years) }\end{array}$ & Sex & Source & Species \\
\hline 71001 & 4 & Female & Scalp & T. inkin \\
71002 & 3 & Female & Scalp & $\begin{array}{c}\text { T. ovoides } \\
71003\end{array}$ \\
71004 & 4 & Female & Scalp & Trichosporon sp. \\
71005 & au & Female & Scalp & T. ovoides \\
71006 & 6 & Female & Scalp & T inkin \\
71007 & 5 & Female & Scalp & T. ovoides \\
71008 & 25 & Male ovoides & Genital & T. ovoides \\
71009 & 2 & Female & Scalp & T. ovoides \\
71010 & 11 & Female & Scalp & T. ovoides \\
\hline
\end{tabular}

a: Culture Collection of INCQS; au: age unununknown.

\section{TABLE II}

Physiological and biochemical tests of Trichosporon ovoides and Trichosporon inkin strains after growth up to four weeks

\begin{tabular}{|c|c|c|}
\hline Tests & T. ovoides & T. inkin \\
\hline \multicolumn{3}{|l|}{ Carbohydrate source } \\
\hline Glucose & + & + \\
\hline Galactose & + & + \\
\hline Sorbose & + or - & - \\
\hline Glucosamine & + or - & + or - \\
\hline Ribose & + & + \\
\hline Xylose & + & + \\
\hline Arabinose & + or - & - \\
\hline Rhamnose & + or - & - \\
\hline Sucrose & + & + \\
\hline Maltose & + & + \\
\hline Trehalose & + & + \\
\hline Methyl-glucoside & + & + \\
\hline Cellobiose & + & + \\
\hline Salicine & + or - & - \\
\hline Melibiose & - & - \\
\hline Lactose & + or - & + \\
\hline Raffinose & + or - & - \\
\hline Melzitose & + or - & + \\
\hline Glycerol & + or - & + \\
\hline Erythritol & + or - & + \\
\hline Adonitol & - & - \\
\hline Dulcitol & - & - \\
\hline Mannitol & + or - & + or - \\
\hline Sorbitol & + or - & - \\
\hline Inositol & + & + \\
\hline Lactate & + & + \\
\hline Succinate & + or - & - \\
\hline \multicolumn{3}{|l|}{ Nitrogen Source } \\
\hline $\mathrm{KNO}_{3}$ & - & - \\
\hline $\mathrm{KNO}_{2}$ & + or & + or - \\
\hline Lysine & + & + \\
\hline \multicolumn{3}{|l|}{ Additional Tests } \\
\hline 0,1\% Cycloheximide & + & + \\
\hline 0,01\% Cycloheximide & + & - \\
\hline Urea & + & + \\
\hline
\end{tabular}

arthroconidia. After 10 days, the cultures were nearly all filamentous with many well-developed arthroconidias that had rectangular or oval shapes (Fig. 2B).

Trichosporon inkin (Oho ex Ota) do Carmo-Souza and van Uden - On YMA after 10 days at $25^{\circ} \mathrm{C}$ the colonies, including T. inkin INCQS 40266 (ATCC 18020), attained 9-12 $\mathrm{mm}$ diameter and were finely cerebriform, without a marginal zone, often cracked the agar, and with a creamy, slightly yellow colour, and older colonies sometimes darkened (Fig. 3A). Microscopically cylindrical or rectangular arthroconidia measuring approximately 2-5 x 3-16 $\mu \mathrm{m}$ were observed after two days of incubation at $25^{\circ} \mathrm{C}$ on MEA. Blastoconidia and sarcinae were observed after 10 days (Fig. 3B). Appressoria were observed in cultures on CMA after 10 days (Fig. 3C).

Clinical observations - The distribution of white piedra agents in patients according to age, sex and source is shown in Table I. Among the 10 fungal isolates collected from hair, nine were from scalp white piedra $(90 \%)$ in female patients, and one was from genital white piedra $(10 \%)$ in a male patient. T. ovoides was isolated as the aetiological agent of white piedra in seven cases (70\%), among them six in hair shaft $(86 \%)$ and one in genital hairs (14\%). T. inkin was isolated from hair shaft samples from two patients $(20 \%)$ and there were no occurrences of white piedra on genital hair produced by this fungus. The only isolate not identified at the species level (10\%) was isolated from hair shaft. T. ovoides was the most frequently isolated $(60 \%)$, once from male patient and six times from female patients. The isolates were deposited in the Culture Collection of INCQS and their corresponding accession numbers are listed in Table I.

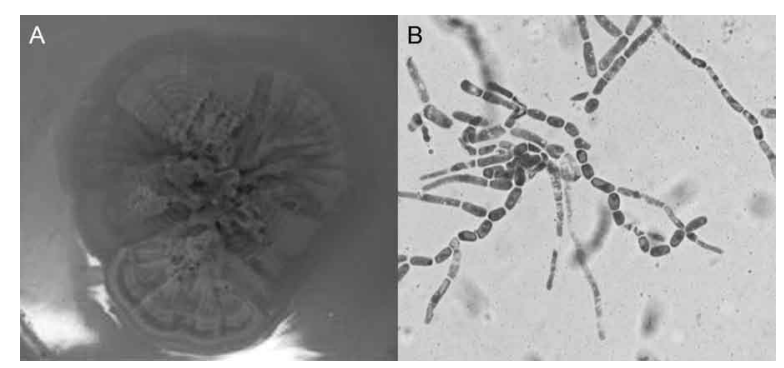

Fig. 2: Trichosporon ovoides: A: yeast colony on YMA; B: hyphae and arthroconidia (Lactophenol cotton blue, 400X).
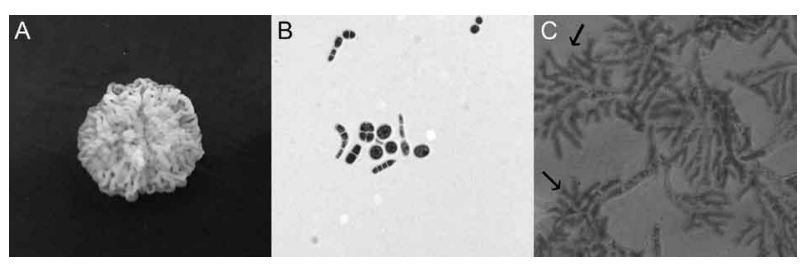

Fig. 3: Trichosporon inkin: A: yeast colony on YMA; B: arthroconidia, blastoconidia and sarcinae (Lactophenol cotton blue, 400X); $\mathrm{C}$ : hyphae and appressoria (arrows) (Lactophenol cotton blue, $400 \mathrm{X}$ ). 


\section{DISCUSSION}

The attack of hairs by Trichosporon spp. is known worldwide as white piedra and is considered a sporadic infection that occurs in tropical and temperate climates (Fishman et al. 1980, Thérizol-Ferly et al. 1994, Elmer et al. 2002, Youker et al. 2003, Ghorpade 2004, Kiken et al. 2006), mostly in rainy periods (Kamalam et al. 1981).

In the few reports of mycoses caused by the genus Trichosporon in Brazil over the last 30 years, genital and scalp white piedra were recorded mainly in the states of São Paulo, Rio de Janeiro, Paraíba and Espírito Santo (Fischman et al. 1980, Gondim-Gonçalves et al. 1991, Pontes et al. 2002a, b, Diniz et al. 2005). In the present study of the 10 Trichosporon species mostly isolated from scalp, $T$. ovoides, considered as the main causative agent of white piedra (Guého et al. 1994), was the predominant species.

Based on Guého et al. (1994), the white piedra was very common in the beginning of the 20th century in Europe and South America. Nevertheless, in the present days, due to improvements in personal hygiene, it has become rarer. In the present investigation, all the patients seemed to have good personal hygiene habits and were of medium socioeconomic status. It was, therefore, not possible to associate the disease with poor personal hygiene. On the other hand, in some cases those in charge of the children reported that they habitually tied back their hair while still wet just after bathing and it was also observed that even the young children used cream conditioners and other hair creams. Diniz and Souza Filho (2005) suggested that those situations could be factors that are favourable for keeping hair wet and consequently for developing mycosis.

White piedra was recorded in Rio de Janeiro by Gondim-Gonçalves et al. (1991) on hair shafts from three children in the age group of 0-10 years. In Paraíba (Pontes et al. 2002b) and in Espírito Santo (Diniz \& Souza Filho 2005), higher numbers of white piedra cases were found in children's scalps. The present investigation corroborates these earlier studies since the majority of the isolates $(70 \%)$ were obtained from scalp white piedra found in children under the age of 10 . The species found most frequently on these children was $T$. ovoides, which is in agreement to the literature that reports this species as the main agent of scalp white piedra (Guého et al. 1994). However, discrepant results were found by Kiken et al. (2006) in USA, who identified T. cutaneum, T. asahii and T. mucoides as the aetiological agents of white piedra in children.

Trichosporon inkin species currently related to some cases of systemic processes (Ramos et al. 1998, Koyanagi et al. 2006) were found in this investigation, causing white piedra in the hair shaft in two patients, one of them a four-year-old child. These results are unexpected in light of those of Guého et al. (1992b, 1994), who demonstrated the strong preference of this species to the genital areas, causing white piedra in pubic hair. To our knowledge this, is the first time that $T$. inkin is identified as a white piedra agent in hair shafts in children under the age of 10 . On the other hand, T. ovoides, traditionally isolated from the hair shaft (Guého et al. 1994, 1998), was identified as the causative agent in the only case of genital white piedra observed in this study.

$T$. inkin and $T$. ovoides are molecularly similar species (Guého et al. 1992b) and even the sequencing of ITS, a DNA region that is highly conserved and very often used for species identification, does not allow the reliable distinction between them, causing some authors to prefer the biochemical characterisation for identification (Koyanagi et al. 2006). In the present investigation, biochemical and physiological characterisation analysed using Yeast Identification PC Program, version 4 (Barnett et al. 2000), resulted in the species identification with a $95-100 \%$ hit probability. These results, together with the morphological characterisations, allowed reliable identifications.

The patients included on this research were mostly females and were under the age of 10 (Table I). These results are in accordance to previous investigations that reported the white piedra cases in hair shaft mainly on female patients in the age group of 0-10 years (Pontes et al. 2002b, Diniz \& Souza Filho 2005, Kiken et al. 2006). This is the first report on T. inkin identified as a white piedra agent in the hair shaft of a child under the age of 10. The species identification of the genus Trichosporon as white piedra agents will contribute to improve the knowledge on this mycosis and on these species.

\section{ACKNOWLEDGMENTS}

To Dr. Regina Cazs Schetmann, dermatologist and head of the Mycology Laboratory at Santa Casa de Misericórdia do Rio de Janeiro, for giving the access to the patients records and to the photographs of the attacked hair, to Elzarlinda Eurich Reis, technician of this same Laboratory, for collecting, preserving and providing the fungal cultures used in the present study, to Miguel M. Fialho and Carlos Roberto S. do Nascimento, from Setor de Fungos de Referência from Departamento de Microbiologia, INCQS/FIOCRUZ, for their collaboration on the photographic documentation.

\section{REFERENCES}

Almeida HL, Rivitti EA, Jaeger RG 1990. White piedra: ultrastructure and a new microecological aspect. Mycoses 33: 491-497.

Barnett JA, Payne RW, Yarrow D 2000. Yeasts: characteristics and identification, 3th ed., Cambridge University Press, London, $1138 \mathrm{pp}$.

Brito A, Costa CAA 1966. "Piedra" em Belém do Pará. An Bras Dermatol 41: 227-228.

Carneiro JA, Alonso AM, Araújo FA 1973. Novos casos de Piedra branca genital (PBG). An Bras Dermatol 48: 133-136.

Carneiro JA, Assis FA, Filho JT, Carvalho CAQ 1971. Piedra branca genital. 40 casos. An Bras Dermatol 46: 265-269.

de Beurmann L, Gougerot H 1909. Les exascoses, Saccharomycoses (mycose de Busse-Buschke) et Parasaccharomycoses. Zymonematoses (mycose de Gilchrist). Parendomycoses et endomycoses (Muguet). Revision et démembrement de l'ancien groupe des Blastomycoses. Bull Mem Soc Med Hop Paris 3: 250-263.

Diniz ML, Souza Filho JB 2005. Estudo de 15 casos de piedra branca observados na Grande Vitória (Espírito Santo-Brasil) durante cinco anos. An Bras Dermatol 80: 49-52. 
Elmer KB, Elston DM, Libow LF 2002. Trichosporon beigelii infection presenting as white piedra and onycomycosis in the same patient. Cutis 70: 209-211.

Fell JW, Boekhout T, Fonseca A, Scorzetti G, Statzell-Tallman A 2000. Biodiversity and systematics of basidiomycetous yeasts as determined by large-subunit $r D N A ~ D_{1} / D_{2}$ domain sequence analysis. Int J Syst Evol Microbiol 50: 1351-1371.

Fischman O, Camargo ZP, Meireles MCA 1980. Genital white piedra: an emerging new fungal disease? 5th International Conference on Mycoses. PAHO Sci Publ 396: 70-76.

Ghorpade A 2004. Surrogate nits impregnated with white piedra - a case report. J Eur Acad Dermatol Venereol 18: 474-476.

Gondim-Gonçalves H, Mapurunga ACP, Melo-Monteiro C, Lowy G, Lima AAB 1991. Piedra branca - revisão de literatura a respeito de três casos. Rev Bras Med 8: 541-544.

Guého E, de Hoog GS, Smith MT 1992a. Neotypification of the genus Trichosporon. Antonie van Leeuwenhoeck 61: 285-288.

Guého E, Improvisi L, de Hoog GS, Dupont B 1994. Trichosporon on humans: a practical account. Mycoses 37: 3-10.

Guého E, Smith MT, de Hoog GS 1998. Description of anamorphic basidiomycetous genera and species: Trichosporon Behrend. In CP Kurtzman, JW Fell, The Yeasts: A Taxonomic Study, 4th ed., Elsevier, Amsterdam, p. 854-872.

Guého E, Smith MT, de Hoog GS, Billon-Grand GC, Christen R, Batenburg-van der Vegte WH 1992b. Contributions to a revision of the genus Trichosporon. Antonie van Leeuwenhoeck 61: 289-316.

Kalter DC, Tschen JA, Cernoch PL, McBridge ME, Sperber J, Bruce S, Wolf JE, 1986. Genital white piedra: epidemiology, microbiology and therapy. J Am Acad Dermatol 14: 982-993.

Kamalam A, Thambiah S, Bagavandas M, Govindaraju S 1981. Mycoses in India - study in Madras. Trans R Soc Trop Med Hyg 75: 92-100.

Kaplan W 1959. Piedra in lower animals. A case report of white piedra in a monkey and a review of the literature. J Am Vet Med Assoc 3: 113-117.

Kiken DA, Sekaran A, Antaya RJ, Davis A, Imaeda S, Silvenberg NB 2006. White piedra in children. J Am Acad Dermatol 55: 956-961.

Koyanagi T, Nishida N, Osabe S, Imamura Y, Yanamoto S, Shichiji A, Nakamura Y 2006. Autopsy case of disseminated Trichosporon inkin infection identified with molecular biological and biochemical methods. Pathol Int 56: 738-743.

Kreger-van Rij NJW 1984. Genus 16. Trichosporon Behrend. In NJW Kreger-van Rij, The Yeasts: A Taxonomic Study, 3th ed., Elsevier, Amsterdam, p. 933-962.
Lacaz CS, Porto E, Martins JEC 1984. Micologia Médica. Fungos, actinomicetos e algas de interesse médico. 7th ed., Sarvier, São Paulo, 479 pp.

Londero AT, Ramos CD, Fischman O 1966. White piedra of unusual localization. Saborouraudia 5: 132-133.

Nora AB, Zoppas B de A, Stefani M, Bombel MG, Ribeiro RG 2002. Piedra branca extragenital: relato de um caso no RS. An Bras Dermatol 77: 473-477.

Pontes ZBVS, Lima EO, Ramos AL, Frade JDMS, Oliveira NMC 2002a. Espécies de Trichosporon Behrend: colonização anal e piedra branca gênito-púbica em pacientes $\mathrm{HIV}^{+}$. Rev Bras Anal Clin 34: 173-175.

Pontes ZBVS, Ramos AL, Lima EO, Guerra MFL, Oliveira NMC, Santos JP 2002b. Clinical and mycological study of scalp white piedra in the state of Paraíba, Brazil. Mem Inst Oswaldo Cruz 97: 747-750.

Ramos JM, Cuenca-Estrela M, Gutierrez F, Elia M, Rodrigues-Tudela JL 1998. Clinical case of endocarditis due to Trichosporon inkin and antifungal susceptibility profile of the organism. J Clin Microbiol 42: 2341-2344.

Schwartz RA 2004. Superficial fungal infections. Lancet 364 : 1173-1182.

Smith JD, Murtishaw WA, McBride ME 1973. White piedra (Trichosporosis). Arch Dermatol 107: 439-442.

Stenderup A, Schonheyder H, Ebbesen P, Melbye M 1986. White piedra and Trichosporon beigelii carriage in homosexual men. $J$ Med Vet Mycol 24: 401-406.

Thérizol-Ferly M, Kombila M, Gomez de Diaz M, Douchet C, Salaun Y, Barrabes A, Duong TH, Richard-Lenoble D 1994. White piedra and Trichosporon species in equatorial Africa. I. History and clinical aspects: an analysis of 449 superficial inguinal specimens. Mycoses 37: 249-253.

Torssander J, Carlsson B, von Krogh G 1985. Trichosporon beigelii: increased occurrence in homosexual men. Mykosen 28: 355-356.

Walzman M, Leeming JG 1989. White piedra and Trichosporon beigelii: the incidence in patients attending a clinic in genitourinary medicine. Genet Med 65: 331-334.

Youker SR, Andreozzi RJ, Appelbaum PC, Credito K, Miller JJ 2003. White piedra: further evidence of a synergistic infection. $J \mathrm{Am}$ Acad Dermatol 49: 746-749.

Zaror LC, Moreno MI, Fishman O, Petri V, Carvalho MTF, Pope S, Porfírio N 1989. Piedra blanca genital. Reporte de três casos. Bol Micol 4: 125-127. 